\title{
REVITALISASI PERAN KONSELOR DALAM KINERJA BIMBINGAN KONSELING DI PESANTREN NURUL JADID
}

\author{
Abu Hasan Agus R, Kutlatul Hasanah \\ Universitas Nurul Jadid Paiton Probolinggo \\ Email: kutlatulhasanah@gmail.com
}

\begin{abstract}
Abstrak: seiring berkembangnya sosial dan budaya, bimbingan konseling sangat urgen membentuk karakter dalam memahami diri (self understanding), menerima diri, mengarahkan diri, dan merealisasikan diri terhadap lingkungan. Bimbingan konseling ternyata tidak hanya dibutuhkan pada level pendidikan formal, melainkan juga dibutuhkan dalam pendidikan nonformal, seperti halnya pondok pesantren yang menyediakan bimbingan konseling sebagai wadah bagi santri untuk menghadapi dan menyelesaikan problematika kehidupan sehari-hari. Konselor pesantren memiliki peran untuk melayani dan membantu para santri dalam menyelesaikan masalah. Konselor juga berfungsi sebagai motivator serta sebagai evaluator dari tindak lanjut masalah yang sesuai dengan penilaian dan keberhasilan layanan yang diberikan oleh konselor. Penelitian ini menggunakan pendekatan kualitatif dengan berdasarkan data hasil observasi dan wawancara yang dilakukan di Wilayah Az-Zainiyah Pondok Pesantren Nurul Jadid untuk mengetahui peran konselor dalam kinerja bimbingan konseling. Dari hasil penelitian tersebut diperoleh beberapa hal penting mengenai peran konselor dalam kinerja bimbingan konseling pesantren. Pertama, membantu para santri dalam menghadapi problematika kehidupan sehari-hari. Kedua, memberi motivasi kepada santri dan pengurus dalam rangka membangun gairah dalam pengabdian. Ketiga, mengimplementasikan hasil pembinaan untuk masa yang akan datang.
\end{abstract}

\section{Kata kunci : bimbingan konseling, peran konselor, pesantren.}

Abstract: In a row progressed social and cultural, counseling guidance is urgent in shaping character in self-understanding, self-acceptance, directing oneself, and realizing the environment. Counseling guidance is not only needed in formal education but non-formal education, such as Islamic boarding schools that provide counseling guidance as a forum for students to face and solve problems of daily life. The pesantren counselor has a role to serve and assist the santri in solving problems, also the counselor has functioned as a motivator, and as an evaluator of the follow-up from a problem in accordance with the assessment and success of the services provided by the counselor. This study uses a qualitative research approach based on data from observations and interviews. conducted in the Az-Zainiyah Region Nurul Jadid Islamic Boarding School to determine the role of counselors in counseling guidance. The results of the study obtained several important things related to the role of counselors in boarding school counseling guidance. First, it helps students to face the problems of daily life. Secondly, motivating students and administrators to develop their self-service in devotion. Third, implement the results of coaching for the future.

Keyword: counseling guidance, the role of the counselor, boarding school. 


\section{PENDAHULUAN}

Bimbingan konseling tidak dapat dipisahkan dengan dunia pendidikan sebagai salah satu sistem pendidikan. Secara mendasar bimbingan merupakan pemberian bantuan secara intens dan sistematis untuk memecahkan suatu masalah yang dihadapi klien, sehingga mampu memahami diri (self understanding), menerima diri (self acceptence), mengarahkan diri (self direction), dan merealisasikan diri (self realization). Sementara konseling lebih sebagai upaya bantuan yang diberikan konselor pada klien dalam rangka mengembangkan potensi, sehingga dapat mengatasi sebuah masalah, yang pada gilirannya mampu menyesuaikan diri dengan lingkungan. ${ }^{1}$

Dalam Undang-undang No. 20 Tahun 2003 tentang sistem pendidikan Nasional, pasal 1 ayat 6, menetapkan dan menegaskan bahwa konselor adalah pendidik. Peran konselor merupakan salah satu tenaga kependidikan yang memiliki keahlian dalam bimbingan dan konseling, serta ahli layanan psikodagogis yang memiliki peran memfasilitasi, membawa manusia berkembang, kondisi apa adanya, dan sebagaimana seharusnya. Dalam arti ini upaya yang dilakukan konselor tidak luput sebagai tempat sharing atau wadah bagi yang memerlukan bimbingan guna menyelesaikan problem yang perlu dipecahkan dan diatasi dengan saksama.

Mengingat konselor dengan kinerja bimbingan konseling sangat berperan aktif memberikan bantuan menyelesaikan problem, maka bimbingan konseling juga memiliki peran dalam membantu santri, bahkan berperan dalam mengembangkan kepribadian sant ri yang mandiri pada masa yang akan datang. ${ }^{2}$ Bimbingan konseling bukan kegiatan pembelajaran dalam konteks belajar dan mengajar layaknya dilakukan guru sebagaimana dalam pembelajaran bidang studi, melainkan layanan ahli dalam konteks memandirikan santri. $^{3}$ Dengan demikian bimbingan konseling merupakan upaya proaktif dan sistematis dalam memfasilitasi santri untuk mencapai tingkat perkembangan yang optimal, pengembangan perilaku yang efektif, pengembangan lingkungan, serta peningkatan fungsi atau mamfaat santri dalam lingkungan. ${ }^{4}$

Selain itu, implementasi layanan bimbingan dan konseling tidak terlepas dari problem solving yang dilakukan seorang konselor terhadap santri. Problem solving adalah suatu proses

\footnotetext{
${ }^{1}$ Rosita Endang Kusmaryani, "Penguasaan Keterampilan Konseling Guru Pembimbing di Yogyakarta", Kependidikan, No. 40. November (2010), hal. 175-86.

${ }^{2}$ Muhammad Nur Wangid, "Revitalisasi Peran Konselor di Sekolah", Paradigma, Juli (2009), hal. 81-92.

${ }^{3}$ Asosiasi Bimbingan dan Konseling Indonesia, 2007. Penataan Pendidikan Profesional Konselor. Naskah Akademik ABKIN

${ }^{4}$ Kamaluddin, "Bimbingan dan Konseling Sekolah", Penddikan dan Kebudayaan, No. 17. April (2011), hal. 447-54.
} 
mencermati masalah baik secara mental maupun intelektual agar dapat mengambil keputusan yang akurat serta mendapat kesimpulan dengan tepat dan cermat. Cara tersebut dilakukan agar dapat mempermudah konselor dalam menangani masalah yang dialami santri.

Terdapat beberapa langkah yang dilakukan konselor saat konseling berlangsung. Pertama, tahap attending, di mana konselor memberi waktu untuk konsultasi dan melakukan attending listening (mendengarkan aktif), Kedua, adalah tahap exploration (menggali informasi). Pada tahap ini dilakukan hubungan responsif. Dalam hal ini seorang konselor harus mempunyai keterampilan-keterampilan yang dibutuhkan. Pertama, question, yaitu dengan cara mengajukan pertanyaan-pertanyaan yang mendorong klien untuk mengungkap suatu masalah. Kedua, reflecting, yaitu kemampuan mengungkap kembali atau pemberian masukan pada klien yang sesuai penjelasan pendapat klien. Ketiga, adalah summaring, yaitu kemampuan untuk menyimpulkan sebuah informasi yang disampaikan klien. Keempat, understanding, yaitu memberi empati untuk memahami perasaan, masalah, dan pendapat klien. Kelima, action, yaitu klien didorong untuk menentukan sendiri tujuan dan rencana yang akan dilakukan untuk memecahkan masalah. ${ }^{5}$

\section{METODE PENELITIAN}

Penelitian ini menggunakan pendekatan kualitatif, sebuah pendekatan yang didefinisikan sebagai penelitan yang tidak melalui proses statistik dan proses kuantifikasi lainnya. Tipe penelitian ini menggunakan tipe studi kasus. Sementara teknik penggalian data yang digunakan dalam penelitian ini adalah wawancara berdasarkan hasil observasi.

Penelitian ini dilakukan di sekitar Wilayah Az-Zainiyah Pondok Pesantren Nurul Jadid Karang Anyar Paiton Probolinggo. Subjek dari penelitian ini adalah konselor sebagai orang yang membantu memberi konseling pada para santri. Ini semua dilakukan untuk mengetahui sejauh mana peran konselor dalam revitalisasi kinerja bimbingan konseling di lingkungan Pesantren Nurul Jadid Paiton Probolinggo. Sementara kerja analisis yang dilakukan dalam penelitian ini adalah analisis tematik dengan menampilkan beberapa tema penting untuk meninjau seberapa jauh peran konselor dalam bimbingan konseling di lingkungan pesantren Nurul Jadid Paiton Probolinggo.

Ruth Grace Aurora and Others, "Peran Konseling Berkelanjutan pada Penanganan Pasien Hiperkolesterolemia’, J Indon Med Assoc, No. 62. Mei (2012), hal. 194-201. 


\section{PEMBAHASAN}

Bimbingan konseling merupakan aksi membantu dalam merencanakan dan mengembangkan potensi diri yang dimiliki oleh seorang individu. Bimbingan bertujuan agar klien dapat memahami dan mengenal potensinya beserta tugasnya, baik dalam keluarga maupun lingkungan. Ini semua dilakukan agar seorang individu dapat menentukan tujuan hidup dan mengembangkan segala potensi dirinya serta mengoptimalkan potensi yang dimilikinya secara tepat dan teratur. Sementara konseling itu sendiri merupakan jantung dari keseluruhan layanan dalam bimbingan.

Dalam konteks di pesantren, bimbingan konseling bertugas melayani dan membina pembinaan diri santri secara emosional, intelektual, dan spritual. Hal ini dilakukan untuk membantu santri baik secara individu maupun kelompok agar mandiri dan dapat mengembangkan potensinya secara optimal sehingga mampu bertindak sesuai dengan normanorma yang berlaku.

Oleh sebab bimbingan dan konseling merupakan kegiatan membantu mengembangkan potensi diri, maka seorang konselor sudah semestinya mempunyai keahlian, potensi, dan kemampuan untuk menangani setiap santri. Pertama-tama implementasi layanan bimbingan dan konseling tidak terlepas dari problem solving dalam proses pelaksanaannya. Sebagaimana dikatakan sebelumnya bahwa problem solving merupakan suatu proses mental dan intelektual dalam mencermati masalah agar dapat mengambil keputusan yang akurat, sehingga mendapatkan kesimpulan secara tepat dan cermat. Cara ini merupakan suatu cara agar pempermudah konselor dalam menangani masalah yang dialami santri.

Pada mulanya sistem problem solving yang diterapkan oleh pihak pesantren dalam menangani permasalahan santri hanya sebatas dilakukan oleh seorang pengurus. Jika dari pihak pengurus tidak dapat memberikan arahan kepada santri, maka selanjutnya penanganan dialihkan langsung kepada bimbingan konseling yang ada di pesantren. Namun, seiring berkembangnya pendidikan pesantren, pihak pesantren membuat program bimbingan dan konseling untuk kemudian merevatalisasi problem solving dalam menangani permasalahan yang dihadapi santri. Program bimbingan dan konseling yang diadakan ini bertujuan untuk membantu santri dalam memahami dan menghadapi suatu masalah agar santri mudah menemukan jati dirinya. 


\section{Revitalisasi Peran Konselor}

Revitalisasi dalam Kamus Besar Bahasa Indonesia memiliki arti suatu proses, cara, perbuatan menghidupkan atau menggiatkan kembali. ${ }^{6}$ Ini menunjukkan bahwa revitalisasi adalah pemunculan kembali sebuah aktivitas dan keunggulan subyek. Maka dari itu, apabila makna tersebut diimplementasikan khususnya dalam proses problem solving, maka menjadi suatu usaha untuk mengembalikan atau memulihkan kembali sebuah kegiatan dan keunggulan sistem yang semestinya diberlakukan.

Berdasarkan realitas yang terjadi di Pondok Pesantren Nurul Jadid, khususnya di Wilayah Az-Zainiyah, pada mulanya sistem problem solving yang diterapkan pihak pesantren dalam menangani permasalahan santri hanya sebatas dilakukan seorang pengurus. Sistem penanganan yang dilakukan oleh pihak pengurus ditangani sendiri. Jika dari pihak pengurus tidak dapat memberikan solusi pada santri, maka penanganan dialihkan langsung ke pengurus bimbingan konseling yang ada di pesantren.

Namun, seiring berkembangnya pendidikan pesantren, pihak pesantren kemudian membuat program bimbingan dan konseling untuk merevitalisasi problem solving dalam hal penanganan permasalahan santri. Dalam hal ini, pengurus yang bertanggung jawab sebagai konselor pesantren harus memiliki beberapa syarat kualitas pribadi, diantaranya, bertaqwa kepada Allah, memberikan teladan baik, memiliki sifat amanah, jujur, konsisten, memiliki rasa empati dan kasih sayang, serta melakukan konseling tanpa pamrih dan memiliki kecakapan pengetahuan tentang layanan bimbingan dan konseling. ${ }^{7}$

Fungsi utama bagi program bimbingan dan konseling di pesantren tidak hanya berpaku pada proses penanganan kenakalan santri, melainkan sebagai wadah bagi santri untuk melakukan sharing ataupun mendapat arahan terkait permasalahan yang dialaminya, baik permasalahan dalam hal belajar, lingkungan, ataupun sosial. Sebagaimana yang terjadi dalam pesantren dengan diadakannya bimbingan konseling bertujuan membantu santri dalam memahami dan menghadapi masalah yang dialami serta mempermudah santri dalam menemukan jati dirinya. Peran konselor dalam bimbingan konseling untuk senantiasa memperingatkan agar santri memahami dan menyadari salah satu tugas pokok. ${ }^{8}$

Kompetensi inti konselor adalah common competention yaitu memiliki seperangkat pengetahuan, sikap, dan keterampilan yang dikuasai seorang konselor dalam setting mana

\footnotetext{
${ }^{6}$ Desy Anwar, Kamus Lengkap Bahasa Indonesia Terbaru (Surabaya: Amelia Surabaya, tt), hal. 370.

${ }^{7}$ Achmad Juntika Nurihsan, Bimbingan dan Konseling dalam Berbagai Latar Kehidupan (Bandung: Refika Aditama, 2018), hal. 30.

${ }^{8}$ Muhammad Nur Wagid, 'Peran Konselor Sekolah dalam Pendidikan Karakter', Cakrawala Pendidikan, Th.XXIX. Edisi Khusus Dies Natalis UNY (2010), hal. 173-86.
} 
pun. Setiap setting bimbingan dan konseling adalah guidance and counseling yakni menghendaki kompetensi khusus yang harus dikuasai konselor untuk dapat memberikan pelayanan dalam setting tersebut. ${ }^{9}$ Dengan demikian seorang konselor harus mempunyai keterampilan yang sesuai dengan tugas pokok seorang konselor.

\section{Peran Konselor terhadap Kinerja Bimbingan dan Konseling di Pesantren Nurul Jadid Paiton Probolinggo}

Bantuan yang diberikan seorang konselor bertujuan untuk membantu santri dalam menghadapi masalah yang dialami sehingga menemukan jalan dalam menyelesaikan masalah. Perkembangan pesantren telah mengubah pola pikir masyarakat pesantren untuk kemudian memperbaiki sistem yang ada di dalamnya. Salah satunya revitalisasi yang dilakukan oleh program bimbingan dan konseling yang ada di pesantren Nurul Jadid. Seorang konselor yang berada dalam lingkungan pesantren memiliki beberapa peran diantaranya sebagai berikut:

1. Konselor sebagai Pelayan

Pelayanan dasar yang dilakukan konselor terhadap santri bertujuan membantu santri dalam mengembangkan prilaku efektif dan keterampilan-keterampilan yang beracuan terhadap tugas-tugas perkembangan diri. Pelayanan dilaksankan menggunakan strategi klasikal dalam dinamika kelompok. Konselor sebagai pelayan yang membantu santri dalam menyelesaikan masalah yang dialami santri terutama dalam bidang pribadi membutuhkan pelayanan khusus agar dapat menemukan titik temu dalam menghadapi dan mengatasi masalah. Melayani dalam arti ini adalah membantu menyiapkan (mengurus) yang diperlukan seorang santri, meneladani, menerima (menyambut) ajakan, serta layanan perihal meladeni. ${ }^{10}$ Program layanan merupakan suatu kesatuan kegiatan yang dimaksud untuk memenuhi kebutuhan pihak tertentu sehingga merasa puas sesuai dengan tujuan program. ${ }^{11}$

Pelayanan yang diberikan oleh seorang konselor dalam bimbingan konseling kepada santri bertujuan untuk mempermudah santri dalam memahami, menghadapi, serta menghadapi masalah yang dihadapi. Oleh karna itu, pemberian layanan kepada santri disesuaikan dengan apa yang dibutuhkan santri seperti, ketidak sesuaian dalam diri santri terhadap lingkungan. Tidak hanya itu, bimbingan dan konseling (Konselor) melayani apapun

\footnotetext{
${ }^{9}$ Hartono Boy Soedarmadji, Psikologi Konseling (Jakarta: Kencana Prenada Media Group, 2012), hal. 66

${ }^{10}$ Tim Penyusun Kamus Pusat Pembinaan dan Perkembangan, Kamus Besar Basana Indonesia (Jakarta: Balai Pustaka, 2007), hal. 646.

${ }^{11}$ Suharsini Arikonto dan Cep Safiruddin Abdul Jabar, Evaluasi Program Pendidikan Pedoman Teoritis bagi Praktisi Pendidikan (Jakarta: Bumi Aksara, 2009), hal. 52.
} 
bentuk masalah yang dihadapi santri. Ini dilakukan agar layanan bimbingan bertujuan membantu santri mengimplementasikan rencana pendidikan, karir, dan sosial pribadi. ${ }^{12}$ Dengan demikian, peran konselor membantu santri dalam memantau dan memahami pertumbuhan perkembangan santri, serta merencanakan dan mengimplementasikan rencana yang sesuai dengan pemantauan dan pemahaman diri sendiri.

Terdapat banyak jenis layanan meliputi pertama, layanan orientasi yaitu layanan yang diberikan untuk pemahaman dan penyesuaian diri terhadap lingkungan baru. Hasil yang diperoleh dari layanan orientasi santri mampu menyesuaikan diri terhadap pola kehidupan sosial, kegiatan belajar, serta kegiatan lainnya yang mendukung keberhasilan.

Kedua, layanan informasi yaitu layanan yang memberikan informasi yang diperlukakan santri. Layanan ini bertujuan membekali santri dengan berbagai pengetahuan dan pemahaman tentang berbagai hal yang berguna untuk kepentingan hidup dan perkembanganya. Dengan diperolehnya informasi yang didapat bertujuan mempermudah santri dalam membuat perencanaan dalam mengambil keputusan.

Ketiga, layanan penempatan dan penyaluran yaitu serangkaian kegiatan bimbingan dalam membantu santri agar dapat menempatkan dan menyalurkan dirinya dalam progam sekolah, kegiatan belajar, ekstrakurikuler, progam latihan maupun pendidikan yang lebih tinggi sesuai bakat dan minat, kemampuan, serta kondisi fisik dan psikisnya.

Keempat, layanan penguasaan konten yaitu layanan bantuan kepada santri untuk menguasai kemampuan atau kompetensi tertentu melalui kegiatan belajar, layanan yang memungkinkan santri dalam mengembangkan sikap dan kebiasaan belajar yang baik, serta berbagai aspek, dan tujuan kegiatan yang lainnya yang berguna bagi kehidupan dan perkembangannya.

Kelima, layanan konseling perorangan yaitu pelayanan secara pribadi melalui tatap muka dengan konselor dalam rangka pembahasan dan pengentasan permasalahan yang dialami oleh santri.

Keenam, layanan bimbingan kelompok yaitu layanan yang memungkinkan sejumlah santri secara bersama-sama melalui dinamika kelompok agar memperoleh berbagai bahan dari narasumber tertentu (terutama guru pembimbing). Adapun pembahasan dalam bimbingan kelompok adalah topik-topik tertentu yang mengandung permasalahan umum yang aktual dan mendorong pengembangan perasaan, pikiran, persepsi, dan sikap yang menunjang terwujudnya tingkah laku yang efektif.

\footnotetext{
${ }^{12}$ Achmad Juntika Nurihsan, Bimbingan dan Konseling dalam Berbagai Latar Kehidupan (Bandung: Refika Aditama, 2018), hal.18.
} 
Ketujuh, layanan konseling kelompok yaitu membicarakan dan menyelesaikan bermacam masalah yang dialami melalui dinamika kelompok. Dalam layanan konseling kelompok pertama-tama dimulai dengan membahas masalah-masalah pribadi dari masingmasing anggota kelompok. Fokusnya adalah pembahasan masalah pribadi hingga diperoleh perencanaan disamping pengembangan perasaan, pikiran, persepsi dan sikap dalam bersosialisasi. $^{13}$

Selanjutnya adalah layanan responsif yaitu suatu layanan bimbingan yang bertujuan membantu memenuhi kebutuhan yang dirasa sangat penting oleh santri. Salah satu yang termasuk layanan responsif ialah pelayanan terhadap bimbingan pribadi dan sosial yang lazim terjadi dalam penangan bimbingan dan konseling. Layanan ini dilakukan untuk membantu santri dalam menyelesaikan masalah-masalah pribadi dan sosialnya, terutama hubungan dengan sesama teman, pemahaman sifat dan pemahaman diri sendiri, serta pemahaman atas lingkungan dalam penyelesaian masalah.

Dalam bimbingan secara pribadi dan sosial dengan cara mengarahkan para santri upaya pemantapan serta mengembangkan kemampuan dalam menangani masalah. Ini dilakukan tiada lain bertujuan pencapaian pribadi yang seimbang dengan memperhatikan keunikan karakteristik pribadi dengan beragam masalah yang dialami santri. Layanan ini yang bermaksud menanamkan sikap-sikap positif pada seorang santri dalam lingkungan, terutama dari segi keterampilan yang sesuai dengan pribadi santri.

Selain itu peran konselor di pesantren membantu dalam pengembangan. Dalam arti ini konselor membantu dalam perencaan dan memilih bidang akademik. Pertama-tama dalam bidang akademik konselor membantu santri dalam menemukan masalah-masalah seperti pengenalan kurikulum, pemilihan jurusan, cara menyelesaikan tugas-tugas, cara menemukan sumber belajar, serta membantu dalam perencanaan pemilihan ke jenjang pendidikan yang lebih tinggi. Tidak hanya dibidang akademik, bahkan peran konselor juga membantu di bidang karir yang merupakan layanan pemenuhan kebutuhan perkembangan individu sebagian integral dari progam pendidikan.

Bimbingan karir adalah upaya bantuan agar mengenal dan memahami dirinya guna mengembangkan masa depan yang sesuai dengan kehidupan yang diharapkan. Dengan cara ini seorang santri dapat menentukan pengambilan keputusan secara tepat dan bertangung jawab atas apa yang menjadi pillihan. Ini dilakukan agar terwujud kemampuan yang dimiliki santri untuk menunjukkan seberapa jauh kemajuan diri dalam melakukan aktifitas

\footnotetext{
${ }^{13}$ Hasil Wawancara dengan Koordinator Bimbingan Konseling di Pondok Pesantren Nurul Jadid, pada Tanggal 10 Januari 2020.
} 
profesionalisme dalam pekerjaan.

2. Konselor sebagai Motivator

Pemberian motivasi diberikan konselor terhadap santri agar memiliki semangat dalam mengadapi dan mengatasi suatu masalah yang dialami santri. Motivasi adalah suatu dorongan dalam diri sendiri baik dari faktor intenal maupun faktor eksternal. Hal utama yang dilakukan seorang konselor adalah dengan cara menasehati. Menasihati merupakan suatu bentuk teknik yang dilakukan seorang konselor dalam bimbingan dan konseling. Dalam pemberian nasihat terhadap santri, maka seorang konselor harus memperhatikan hal-hal berikut:

a. Berdasarkan masalah atau tingkat kesulitan yang dihadapi oleh santri.

b. Diawali dengan menghimpun data yang berkaitan langsung dengan masalah yang dihadapi santri.

c. Nasihat yang diberikan bersifat alternatif yang dapat dipilih oleh seorang santri, disertai analisis sebuah kemungkinan-kemungkinan keberhasilan dan kegagalan.

d. Penentuan keputusan diserahkan pada santri yakni alternatif mana yang akan diambil.

e. Santri mau tidak mau mampu mempertanggung jawabkan keputusan yang diambil. ${ }^{14}$

Berdasarkan poin di atas, motivasi yang diberikan konselor merupakan sikap konselor dalam menghadapi situasi kerja, sebuah kondisi yang menggerakkan diri santri dalam mengemban tugas sebagaimana semestinya. Tujuan kerja motivasi tidak lain agar santri tidak lagi mengulang kesalahan yang telah berlalu. Dengan cara ini tugas seorang konselor dalam memotivasi agar santri bisa memilih mana yang baik dan tidak untuk dirinya dan pada masa yang akan datang.

Selain itu, strategi yang digunakan oleh seorang konselor dalam bimbingan dan konseling salah satunya memotivasi agar diri seorang santri mampu menemukan jati dirinya. Setidaknya ada dua macam motivasi yang menjadi unsur terpenting yakni, motivasi dalam diri santri (internal) dan motivasi yang datang dari orang lain (eksternal). Motivasi internal misal seperti mampu menghilangkan rasa malas, semangat belajar, dan mampu menyelesaikan masalah dengan baik. Hal ini dilakukan karena manusia diciptakan untuk saling tolong menolong, baik dalam keadaan susah maupun senang.

Oleh sebab motivasi memiliki banyak segi, maka membantu sesama teman dalam lingkup pesantren sangat berperan penting terutama dalam bimbingan konseling yang sangat diperlukan dalam lingkup santri. Dalam proses pemberian motivasi tidak hanya terdiri dari satu komponen, melainkan banyak komponen yang saling terkait satu sama lainnya, sehingga

\footnotetext{
${ }^{14}$ Achmad Juntika Nurihsan, Bimbingan dan Konseling dalam Berbagai Latar Kehidupan (Bandung: Refika Aditama, 2018), hal. 23
} 
banyak masalah yang mesti dipecahkan secara bersama serta penanganan secara saksama.

3. Konselor sebagai Layanan Evaluasi dan Tindak Lanjut

Sesuai dengan penilai dan keberhasilan layanan bimbingan yang diberikan, maka harus diadakan evaluasi. Adanya evaluasi karena akan ada tindak lanjut untuk menyempurnakan apa yang sudah dilakukan oleh konselor kepada santri. Layanan evaluasi ini menyangkut evaluasi proses dan evaluasi hasil yang telah diberikan konselor atas terlaksananya bimbingan. Proses evaluasi sebagai bentuk untuk mengukur sejauh mana terlaksannya bimbingan dan konseling yang didukung atau tidak oleh berbagai komponen yang terkait dengan sumber pelaksanaannya. Hal ini dilakukan tiada lain untuk melihat efektifitas kinerja bimbingan dan konseling yang terdapat di lingkungan pesantren.

Setelah melalui beberepa tahap bimbingan dan konseling, maka evaluasi dan tindak lanjut langsung dilakukan oleh pengurus (wali asuh). Sementara pengurus bagian bimbingan dan konseling pesantren memonitoring sampai dimana usaha yang telah dilakukan konselor terhadap santri.

\section{Kinerja Bimbingan Konseling}

Dalam pelaksanaan bimbingan dan konseling, kinerja yang dilakukan oleh seorang konselor menjadi salah satu titik acuan keberhasilan dalam sistem bimbingan dan konseling. Kinerja ini memiliki tiga faktor penentu yakni: kemampuan perangai dan minat kerja, motivasi, dan kejelasan peran. Untuk membentuk efektivitas kerja, maka konselor memiliki kemampuan mengerjakan tugasnya, serta keinginan melakukan tugas dan mengerti apa yang seharusnya menjadi tuganya. Maka dengan cara ini seorang konselor menjadi profesionalisme, sehingga dalam perkembangan kinerjanya selalu memiliki makna positif dalam arti normatif, seperti kualitas kerja, disiplin, jujur, giat, produktif ${ }^{15}$.

Terkait dengan kinerja bimbingan konseling, wujud perilaku dilakukan konselor melalui kegiatan bimbingan konseling. Dalam prosesnya melalui beberapa tahapan: merencanakan, pelaksanaan, mengevaluasi program bimbingan konseling. ${ }^{16}$ Kinerja bimbingan konseling dapat diukur menjadi empat faktor. Pertama, quality of work yakni kualitas perkerjaan); kedua, promptness yaitu ketepatan waktu dalam menyelesaikan pekerjaan; ketiga, initiative yaitu prakarsa untuk menyelesaikan pekerjaan; keempat,

\footnotetext{
${ }^{15}$ Lastony Budy Hartono, Hubungan antara Kemampuan Manajerial Kepala Sekolaah dan Supervisi Bimbingan Konseling dengan Kinerja Guru Bimbingan SMP Negeri se-Kabupaten Jepara (Jepara: Program Pascasarjana Universitas Negeri Semarang, tt), hal. 33.

${ }^{16}$ Yekti Endah P dan Sugiyo, "Kinerja Guru Bimbingan dan Konseling: Studi Kasus di Sman', Bimbingan Konseling, No. 5. Januari (2016), hal. 37-46.
} 
communication yaitu kemampuam membina kerja sama dengan pihak lain. ${ }^{17}$

Sementara berdasarkan peran yang dilakukan oleh seorang konselor mencakup tiga hal, yakni perencanaan layanan bimbingan konseling, pelaksanaan layanan bimbingan konseling, evaluasi pelaporan dan tindak lanjut. ${ }^{18}$ Dalam arti ini pelayanan yang dilakukan pengurus bimbingan dan konseling kepada santri dalam bentuk pembinaan spiritualis dan emosional santri. ${ }^{19}$ Pembinaan spiritualis meliputi pembinaan al-Quran dan furudul ainiyah, ${ }^{20}$ sedangkan pembinaan emosional santri meliputi pembinaan akhlak dan mengayomi dalam membentuk karakter santri.

Dalam konteks ini Pesantren Nurul Jadid memiliki sistem bimbingan dan konseling yang mampu melayani setiap santri untuk menemukan dan mengembangkan potensi yang ada dalam dirinya. Melalui wali asuh yang bekerja sama dengan bagian bimbingaan dan konseling, pelayanan bimbingan santri memberikan dampak cukup signifikan bagi praksis pendidikan pesantren. Adapun kinerja yang dilakukan bimbingan konseling dalam upayanya memberikan pelayanan pada santri cukup baik dengan diawali pembinaan wali asuh pada santri melalui pembinaan baca tulis Quran, pembinaan furudul ainiyah dan akhlakul karimah.

Sementara dari segi afektif mencakup kepedulian santri terhadap lingkungan dan kebersihan yang pelayanannya melakukan menajemen room. Usaha ini dilakukan agar santri bisa berperilaku hidup sehat serta menciptakan lingkungan rapi-bersih nan indah. Selain itu juga dilakukan pembinaan akhlak melalui pemberian materi dan diimplementasikan langsung oleh santri pada sesama temen dan pengurus.

Sementara itu, dalam usaha menanggulangi kenakalan santri memerlukan pembinaan khusus dalam bimbingan konseling. Ada beberapa macam teknik pelaporan. Pertama, laporan langsung yang diajukan oleh pihak wali asuh kepada konselor. ${ }^{21} \mathrm{Kedua}$, laporan dari mahkamah pesantren kepada konselor. Laporan pertama dalam prosesnya dilakukan langsung oleh wali asuh sendiri pada santri. Apabila dalam pembinaan wali asuh tidak mampu mengubah sikap santri dan tidak memberi efek jera, maka penanganannya dialihkan langsung pada konselor yang ada di pesantren. ${ }^{22}$ Sedangkan laporan yang diajukan pihak mahkamah

\footnotetext{
${ }^{17}$ Nursalim, M, Pengembangan Profesi Bimbingan \& Konseling (Jakarta: Erlangga, 2015), hal. 62.

18 Daryanto, Farid M, Bimbingan Konseling Panduan Guru BK dan Guru Umum (Yogyakarta: Gava Media, 2015), hal. 75.

${ }^{19}$ Farhan dan Aziah, "Upaya Wali Asuh pada Peserta Asuh Mengatasi Bullying di Pesantren Nurul Jadid Perspektif Komunikasi Persuasif', Riset dan Konseptual. No. 4. Januari (2019), hal. 46-55.

${ }^{20}$ Alfi Najmatil Ilmy, Abd Hamid Wahid, Chusnul Muali, "Urgensi Keterlibatan Wali Asuh dalam Dinamika Pendidikan di Pesantren. Pendidikan Agama Islam. Vol. 6 No. 1 (2018), hal. 44-66.

${ }^{21}$ Hasil Wawancara dengan Ustdazah Nur laily Fitriana, pada tanggal 25 Januari 2020.

${ }^{22}$ Hasil Wawancara dengan Uswatun Hasanah, Pada tanggal 25 Januari 2020.
} 
langsung ditangani oleh konselor pesantren.

Dari semua penjelasan di atas dapatlah dikatakan bahwa kinerja bimbingan konseling dalam menangani permaslahan yang dihadapi santri, pertama, pemberian motivasi terhadap santri yang di dalamnya meliputi dorongan untuk berperilaku baik dan benar serta mengimplementasikan langsung terhadap lingkungan. Kedua, memonitoring bimbingan konseling pada santri melalui wali asuh untuk mengetahui sejauh mana proses yang dilakukan konselor.

\section{KESIMPULAN}

Dari pemaparan diatas dapat ditarik benang merah bahwa peran bimbingan dan konseling sebagai wadah untuk konsultasi serta membantu santri dalam menghadapi permasalahan yang terjadi dalam lingkup pesantren dapat dikatakan sangat signifikan. Peran konselor sebagai motivator supaya santri semangat dalam menjalani kehidupan pada masa yang akan datang, sehingga dapat membantu santri menyelesaikan tugas-tugasnya. Dengan adanya bimbingan konseling di pesantren dapat mempermudah santri, wali asuh, dan pengurus dalam menghadapi problematika di lingkungan pesantren. Maka dengan adanya pelayanan yang intensif dari konselor, santri mampu memahami dirinya dan lingungan sosialnya.

Pada titik ini peran konselor tidak hanya sekadar melayani dan menyelesaikan masalah, melainkan sebagai tempat sharing yang mampu memberi semangat dalam pengabdian. Melalui bimbingan konseling yang dilakukan konselor, maka santri mampu membawa dirinya menghadapi suatu keinginan yang akan dituju pada masa yang akan datang. Dengan cara ini dapat menambah semangat diri santri melaksankan tugas sebagai insan, dan khususnya menjadi santri di pondok pesantren Nurul Jadid Paiton Probolinggo.

\section{DAFTAR PUSTAKA}

Anwar, Desy, Kamus Lengkap Bahasa Indonesia Terbaru. Surabaya: Amelia Surabaya, tt.

Arikonto, Suharsini dan Jabar, Cep Safiruddin Abdul, Evaluasi Program Pendidikan Pedoman Teoritis bagi Praktisi Pendidikan. Jakarta: Bumi Aksara, 2009.

Asosiasi Bimbingan dan Konseling Indonesia, 2007. Penataan Pendidikan Profesional Konselor. Naskah Akademik ABKIN. 
Aurora, Ruth Grace and Others, "Peran Konseling Berkelanjutan pada Penanganan Pasien Hiperkolesterolemia', J Indon Med Assoc, No. 62. Mei (2012).

Daryanto, Farid M, Bimbingan Konseling Panduan Guru BK dan Guru Umum. Yogyakarta: Gava Media, 2015.

Endah, P Yekti dan Sugiyo, 'Kinerja Guru Bimbingan dan Konseling: Studi Kasus di Sman', Bimbingan Konseling, No. 5. Januari (2016).

Farhan dan Aziah, "Upaya Wali Asuh pada Peserta Asuh Mengatasi Bullying di Pesantren Nurul Jadid Perspektif Komunikasi Persuasif', Riset dan Konseptual. No. 4. Januari (2019).

Hartono, Lastony Budy, Hubungan antara Kemampuan Manajerial Kepala Sekolaah dan Supervisi Bimbingan Konseling dengan Kinerja Guru Bimbingan SMP Negeri seKabupaten Jepara` Jepara: Program Pascasarjana Universitas Negeri Semarang, tt.

Hasil Wawancara dengan Koordinator Bimbingan Konseling di Pondok Pesantren Nurul Jadid, pada Tanggal 10 Januari 2020.

Hasil Wawancara dengan Ustdazah Nur laily Fitriana, pada tanggal 25 Januari 2020.

Hasil Wawancara dengan Uswatun Hasanah, Pada tanggal 25 Januari 2020.

Ilmy, Alfi Najmatil, Wahid, Abd Hamid, Muali, Chusnul, "Urgensi Keterlibatan Wali Asuh dalam Dinamika Pendidikan di Pesantren. Pendidikan Agama Islam. Vol. 6 No. 1 (2018).

Kamaluddin, "Bimbingan dan Konseling Sekolah", Penddikan dan Kebudayaan, No. 17. April (2011).

Kusmaryani, Rosita Endang, "Penguasaan Keterampilan Konseling Guru Pembimbing di Yogyakarta”, Kependidikan, No. 40. November (2010).

Nurihsan, Achmad Juntika, Bimbingan dan Konseling dalam Berbagai Latar Kehidupan. Bandung: Refika Aditama, 2018.

Nursalim, M, Pengembangan Profesi Bimbingan \& Konseling. Jakarta: Erlangga, 2015.

Soedarmadji, Hartono Boy. Psikologi Konseling. Jakarta: Kencana Prenada Media Group, 2012.

Tim Penyusun Kamus Pusat Pembinaan dan Perkembangan, Kamus Besar Basana Indonesia. Jakarta: Balai Pustaka, 2007.

Wagid, Muhammad Nur, 'Peran Konselor Sekolah dalam Pendidikan Karakter', Cakrawala Pendidikan, Th.XXIX. Edisi Khusus Dies Natalis UNY (2010).

Wangid, Muhammad Nur, "Revitalisasi Peran Konselor di Sekolah”, Paradigma, Juli (2009). 